\title{
БІБЛІЙНІ НАЗВИ-СИМВОЛИ ТА КОЛЕКТИВНИЙ ЕТИЧНИЙ ДОСВІД (НА МАТЕРІАЛІ УКРАЇНСЬКИХ ПАРЕМІЙ)
} паремій).

Малюга Н. М. Біблійні назви-символи та колективний етичний досвід (на матеріалі українських

У статті проаналізовано паремії з біблійними назвами-символами, які втратили безпосередні зв'язки з біблійно-філософським осмисленням понять, унаслідок чого усталені комплекси набувають народно-розмовного характеру, переміщуються оцінні характеристики, виникає побутове бачення образів; порушено проблему незбігу біблійних моральних постулатів та колективного етичного досвіду, акумульованого в пареміях.

Ключові слова: біблійні назви-символи, паремії, християнський, українська ментальність.

Малюга Н. Н. Библейские названия-символы и коллективный этический опыт (на материале украинских паремий).

В статье проанализированы паремии с библейскими названиями-символами, которые потеряли непосредственные связи с библейско-философским осмыслением понятий, в результате чего стойкие комплексы приобретают народно-разговорный характер, смещаются оценочные характеристики, возникает бытовое видение образов; раскрыта проблема несоответствия библейских моральных постулатов и коллективного этического опыта, аккумулированного в паремиях.

Ключевые слова: библейские названия-символы, паремии, христианский, украинская ментальность. paremies)

Malyuga N. M. The biblical names-symbols and collective ethnic experience (on the base of Ukrainian

The article considers the paremies with biblical names-symbols, which have lost the direct connections with biblical-philosophical sense of concepts, as the result the permanent complexes get national-colloquial character, the estimating characteristics are removing, the everyday vision of images appears; the problem of non-combination of the biblical moral postulates and collective ethnic experience, accumulated in the paremies, is raised here.

Key words: biblical name-symbols, paremies, Christian, Ukrainian mentality.

Усвідомлення минущості людського життя змушує звертатися до тих цінностей, що в Біблії трактуються 3 позиції вічного тривання. Український фольклор, який живили християнські ідеї, містить глибоко символічну інформацію про світовідчуття людини, пріоритети її буття й мірила моральності вчинків. Паремійний фонд засвідчує незбіг біблійних моральних постулатів та колективного етичного досвіду, етичного вибору людей, об'єднаних не лише територіально, а й ментально.

Мета нашої розвідки - проаналізувати українські паремії 3 біблійними назвами-символами, які втратили безпосередні зв'язки 3 біблійно-філософським осмисленням понять.

Як тонко підмітила Н. Бабич, іменем Бога клянуться і проклинають, застерігають i зупиняють, примиряють і вибачають, благословляють i дорікають, узагальнюють досвід предків i повчають 3 огляду на відповідальність перед майбутнім [1, с. 122]. Тому не дивно, що в українській мові побутує велика кількість стійких одиниць, у яких смислоутворювальним ядром є слово Бог: Нема в світі над Бога [6, с. 20]; Над Богом нема нікого [6, с. 20]; Без Бога ні до порога [6, с. 20]; Усі під Богом ходимо (Усі ми під Богом) [6, с. 20]; Кому Бог поможе, то все 
переможе [6, с. 20]; У Бога все мога; У Бога все готово [6, с. 20]; Без Божсї волі і волос з голови не спаде (Волос з голови не спаде, як того схоче Бог) [6, с. 20]; Хто в Бога просить, тому й Бог дає [6, с. 22]; Від серияя до Бога навпростець дорога $[6$, с. 22] і т. ін.

Бог у біблійному значенні - «творець усього сущого, що керує світом і вчинками людей»; в образному вживанні - носій найвищих людських ідеалів, моральної довершеності, утілення ідеї людського щастя, справедливості. У філософському трактуванні бог - «фантастичний образ надприродної всемогутньої істоти, яка начебто створила світ і керує ним» [7, с. 37]. Однак залучення більшої кількості сталих одиниць до лінгвоаналізу, зокрема таких: Ніхто з Богом контракту не брав [6, с. 21]; На Бога не дуже гримай [6, с. 21]; 3 Богом не битись, його свята воля [6, с. 21]; До Бога з києм не підеш [6, с. 21]; Силою в Бога не взяти [6, с. 21]; 3 Богом не будеш позиватись [6, с. 21], - дозволяє переконатися у виваженості спостережень та обгрунтованості висновків В. Мокієнка, що «це слово розчинилося у сплаві всього словосполучення, повністю обірвало семантичні зв'язки, які пов'язували його колись із міфологією, i живе сучасним життям у добу підкореного атома й космонавтики» [5, с. 132]. У наведених пареміях під названу одиницю важко підвести словникове тлумачення «у релігійних віруваннях творець, що створив світ і керує ним та вчинками людей» [2, с. 58].

Досить часто в пареміях на закріплене словниками значення нашаровуються додаткові:

- «всемогутній», «свавільний» (у значенні «діє, керує на власний розсуд»): Вольно Богу, щзо хотіти, то чинити [6, с. 20]; Вольно Богу, $i$ зв'язавши, в рай укинути [6, с. 20]; Хто ж у світі знає, щзо Біг гадає! [6, с. 20]; Божих сил не можна вгадать [6, с. 20]; Коли Бог не годить, то й вогонь не горить [6, с. 20]; Як Бог годить, то й мокре горить [6, с. 20]; Як Бог не поможе, то й святі не оборонять [6, с. 20]; Як Бог не схоче, хоч би десять голів мав, то нічого не зробии [6, с. 20]; Божа воля, Божа й сила [6, с. 20];

- «справедливий і відповідальний»: Бог судить не так, як люди [6, с. 21]; Бог багатий, то й нам дасть [6, с. 20]; Біг усе дає, як сам знає [6, с. 20]; Бог знає, щзо робить [6, с. 20]; Бачить (знає) Бог з неба, щуо кому треба [6, с. 21]; Кого Бог сотворить, того не уморить [6, с. 21]; Дав Бог роток, дасть і кусок [6, с. 21]; Що вбогий, щуо багатий - у Бога все рівно [6, с. 21]; Дасть Бог день, дасть і пожиток [6, с. 21]; За сиротою сам Бог з калитою [3, с. 221];

- «господар»: Бог - старий господар, має більше, ніж роздасть [6, с. 21]; Більше Бог має, як роздав [6, с. 21];

- «батько»: Бог - батько, государ - дядько [6, с. 21]; Боже Батьку! Прийми гріхи наші в жарти [6, с. 22]; Бог - батько: як буде нас тримати, то й буде годувати [6, с. 21]. 
Релігійні уявлення поєднуються 3 реаліями життя. Переосмислюючись в українському мовному оточенні під впливом етнолінгвістичних чинників, способу життя, традицій, старовинних вірувань, біблійні символічні назви наближалися до повсякденного побутового, уснорозмовного, фольклорного вживання. Світ сприймається через селянський вимір, відтак в українському фольклорі образ Бога невіддільний від образу селянина. Наприклад: Нам Бога не вчить, як хліб родить [6, с. 21]; Коли сіно в стозі, то забув о Бозі [6, с. 21]; Коли Бог не попустить, то свиня не вкусить [3, с. 48]; Бог не попустить, свиня не з ӥсть [3, с. 48]; Не родить рілля, але Божа воля [3, с. 48].

Людина протиставляє себе Богові, усвідомлюючи, що вона йому нерівня, що вона грішна: Чоловік мислить, а Бог рядить (керує) [6, с. 21]; Чоловік гадає, а Бог розполагає [6, с. 21]; Чоловік стріляє, а Бог кулі носить [6, с. 21]; Чоловік крутить, а Бог розкручує [6, с. 21]; 3 Богом не $з$ хлопцем жартувати [6, с. 21]; Хто чого не знає, тому то Бог прощуає [6, с. 22]; Як не прийме Біг гріхи за жарт, то буде шелесту багато [6, с. 22]; Гріх не гріх, аби Бог простив [6, с. 22]; Бог те знає, а не ми грішні [6, с. 20]; Усе Божеє, тільки гріхи наші [6, с. 20]. I водночас наділяє Бога суто «мирськими» рисами (має органи чуття (плоть), несправедливий, спонукає до розбрату). Бог антропоморфний, відтак ніщо людське йому не чуже: Бог нерівно ділить: жде, щуоб самі ділилися [6, с. 21]; Бог усе бачить, та не скаже [3, с. 48]; Бог видить $i$ знає, але нікому не скаже [3, с. 48].

Нездоланна віра в допомогу Спасителя (так, православні переконані, що у Великодню ніч сам Господь відкриває небо, аби почути й виконати заповітне бажання кожної людини, яка цього варта) трансформується у споживацьке ставлення до Бога: Пошли, Боже, 3 неба, чого нам треба [6, с. 22]; Як Бог дасть, то й у вікно подасть [6, с. 20]; Кому Господь має щзо дати, то дасть і в хаті [6, с. 20]; Як Бог дасть, то й mуm завдасть [6, с. 20]; Господи помилуй - або дай щуо!; Господи помилуй та грошей дай [6, с. 22]; Оиче тобі, Господи, оцуе мені! [6, с. 23]; Боже, поможи, отут i положи! [6, с. 23]; Боже, дай добре, та недовго ждати [6, с. 23]. Як бачимо, у паремійному контексті слова Бог, Господь звучать не так, як у тексті біблійному.

Чималий пласт паремій фіксує високу моральність народу, має повчальний характер, наприклад: Хто - коли тривога, то до Бога, а по тривозі забуде о Бозі-горе тому [6, с. 21]; Коли зле гадаєш, чом же Бога благаєш! [6, с. 21]; На Бога пеняєш, а сам кульгаєш [6, с. 21]; 3 Богом нічого жартувати [6, с. 21]; Хто з Богом, з тим Бог [6, с. 21]; Хто проти Бога, то й Бог проти нього [6, с. 21]; Якмога коло Бога [6, с. 21]; проголошує необхідність працювати «у поті чола свого», відповідати за свої вчинки, виважено підходити до всього, що підносить життєвий шлях, наприклад: На Бога надійся, а сам не плошай [6, с. 21]; Не все ж Біг дарує, 
про щзо люд міркуе [6, с. 21]; Не все до Бога: треба й до розуму свого [3, с. 488]; На Бога покладайся, а розуму тримайся [3, с. 488]; На Бога складайся, розуму ж тримайся [6, с. 21]; Богу молись, а сам стережись [6, с. 21]; «Дай, Боже!» - «Роби небоже!»; "Поможи, Боже!» - «Роби небоже, то й Бог допоможе!» [6, с. 21]; «Поможи, Боже!»- «А ти не лінуйсь, небоже» [3, с. 14]; Богу молись, а сам трудись, бо з голоду здохнеш [3, с. 14]; Богу молись, а до берега гребись [6, с. 23]; Бога взивай (благай), а руки прикладай [3, с. 488]; Боже, поможи, а сам (а ти, небоже) не лежи [3, с. 488]. Народні поради далекі від моралізаторства. Такі одиниці містять сконцентровану філософію поколінь, засновану на історичному досвіді, вони $є$ виразниками української ментальності (релігійність і працелюбність), у пареміях знаходять вияв моральноестетичні зв'язки людини 3 навколишнім світом, із Всесвітом.

Символічне значення слова сягає корінням у давню слов'янську міфотворчість, де божество - це i доля, щастя; таке тлумачення опосередковано зберігається в словесних формулах типу Бог дасmь, Бог в поміч, $з$ Богом тощо [4, с. 71]. Слово-символ Бог містить компоненти «всемогутність», «невідворотність», «справедливість», «всеохопленість», «всебачення», «доля», «кара».

У слов'янскій міфології знаходимо постійне перегукування між словами Бог і доля «Доля 1. Перебіг подій, збіг обставин, напрям життєвого шляху, що ніби не залежить від бажання, волі людини.* У порівн. // Умови життя; життєвий шлях і те, що на ньому виникає. // Бажане, щасливе життя. 2. Стан, у якому перебуває або перебуватиме щонебудь; майбутнє чогось» [2, с. 237]. У філософському тлумаченні, доля поняття, що виражає релігійно-ідеалістичне уявлення про надприродну силу, яка визначає всі події в житті людей. 3 часом долю почали розуміти як верховну справедливість, що керує світом. У християнстві доля постає як божественний промисел, вища сила. Уявлення про долю як божественне приречення притаманне всім сучасним релігіям (фаталізм). У нефілософському смислі поняття доля використовується також для позначення збігу обставин у житті людини чи всього народу [7, с. 359].

Українські паремії фіксують типові ситуації, коли «людина доручає себе, свою долю і повсякденні клопоти Богові, не сумнівається у своїй залежності від його волі, сповнена надії за волю добру і вдячна за неї» [1, с. 120]. Наприклад: Як божа воля, то виринеш з моря [6, с. 20]; Бог знайде, хоч $і$ в печі замуруйся (хоч і під піччю) [6, с. 21] (пор. Доля і на печі знайде); Як Бог дасть, і в печі не замажешся [3, с. 48]; Що Бог не робить, то все на кращуе [6, с. 21]; Що Бог дасть, то не напасть [6, с. 21].

Людина боїться спокути за порушення заповідей Божих, тому досить частотними є паремії, у яких яскраво простежується асоціація Бог / кара. Кара 1. Суворе покарання, відплата за що-небудь. * У порівн. // Катування. // Страта. ** [Чиста] кара божа (Господня) - уживається для вираження 
сильного незадоволення ким-, чим-небудь; горе, нещастя, напасть [2, с. 416]: Кого Бог любить, того й карає [6, с. 21]; Каравии, Бог та ци змилується [6, с. 21]; Бог дасть нуждочку, Бог дасть, щуо й оздоровить [6, с. 21]; Кого Бог засмутить, того й потіиить [6, с. 21]; Бог покорить, Бог $i$ простить [6, с. 21]; Бог хоч не скорий, та влучний [6, с. 21]; Од Бога ніде не сховаєися [6, с. 21]; Од людей сховаєшся, а од Бога ні [6, с. 21]; Бог все бачить, та не скаже (а вже разом покарає на тім світі) [6, с. 21]; Бог не карає прутом [6, с. 21]; Бог не трубить, коли чоловіка губить [6, с. 21]; Біг покорить, Біг $i$ простить [6, с. 21].

Утрачаючи безпосередній зв'язок із біблійно-богословським осмисленням поняття, частина зворотів зі словом Бог набуває народнорозмовного, зниженого характеру; за таких умов оцінні характеристики переміщуються у площину нульової відмітки; інколи виникає відтінок спрощеного, власне побутового бачення образу, елемент гумористичного «запанібратства» [3, с. 72]. Наприклад: 3а сеє Бог не повісить [6, с. 22]; Обіияяв Бог дати, тільки казав заждати [6, с. 23]; Бог Богом, а люди людьми [6, с. 23]; Прости, Боже, сей раз та щуе десять разів: а там побачимо [6, с. 23].

Немало i таких стійких поєднань та образних зворотів, які явно спростовують ізсередини християнські семантичні нашарування i повертають нас саме до язичницьких уявлень про богів: Який Бог змочив, такий $i$ висушить [6, с. 21] (відсилання до Мокоші - богині дощу i плодючості); 3 одним богом на сто ворог [6, с. 20]. Наведені паремії зберігають явні сліди колишнього багатобожжя, характерного для язичників, а також ієрархії великих і малих богів, відповідно до якої кожний рід, сім'я і навіть окрема людина мали власне божество (свого божка, ідола, кумира).

Існують приказки, які однаковою мірою висміюють і православного Бога і язичницьких божків: У Бога щзодня празник! [6, с. 23] (прозорий натяк і на велику кількість релігійних свят - святців, і на закріпленість за кожним днем тижня вшанування певного язичницького бога: понеділок день Хорса, вівторок - Стрибога, середа і п’ятниця - Мокоші, четвер Перуна, субота - Семаргла, неділя - Даждьбога); пор. рос.: Не тому богу попь наши молятся; Плохого бога (идола) и телята лижут; Всем богам по сапогам; Карманный бог помилует. На думку В. Мокієнка, яка нам видається цілком виваженою й обгрунтованою, «причину такого співіснування християнського та язичницького уявлень про бога, настільки протипоставлених одне одному ідеологічно, можна пояснити поступовістю переростання і вростання однієї міфологї̈ в іншу» [5, с. 138].

До нашого аналізу ми залучили лише кілька білійних назв-символів, у тлумачення яких за християнською традицією, з одного боку, та в паремійному фонді української мови, з іншого, - нам видається показово 
розбіжним. Серед них слова, що позначають осіб (Святий, nin) та предметні поняття (церква).

Святий 1. Пов'язаний з релігією, Богом, наділений божественною силою. // Перейнятий божественною силою. 2. Який, за християнською релігією, провів життя у служінні Богові та якого після смерті церква визнала небесним заступником віруючих. // Праведний. Непорочний, угодний Богові. // Люди, які все життя присвятили служінню Богові й після смерті визнані церквою небесними заступниками віруючих. 3. Стос. до Великодня. // Уживається як постійний епітет до свят, визначених християнською релігією. 4. перен. Морально чистий, благородний, бездоганний у житті, поведінці тощо. // Не винний у чому-небудь, перед кимсь; безгрішний. // у знач. ім. святий, свята. Людина, яка не винна ні в чому, ні перед ким. // Чистий, благородний. // Який виражає чистоту, благородство. // Освячений високою метою. // Особливо почесний. 5. Якого глибоко шанують; дорогий, заповітний. // у знач. ім. святе. Те, що глибоко шанують. // Непорушний, непохитний. // Якого мають дотримуватися всі, обов'язковий для всіх. // Звичний, природний, особливо бажаний [2, с. 1110].

До Святих ставлення умотивовано шанобливе: 3 голого, як iз Святого, не візьмеш нічого [3, с. 222]; На голому, як на Святому, нічого не зищещ [3, с. 222 ]. Святим паремії відводять функцію посередників між Богом і людьми, спостерігаємо зміщення перспективи: Через Святих до Бога, через добрих людей до попа [6, с. 21]; Через слуг до пана, а через Святих до Бога [6, с. 22].

Лексема Святий, як і слово-символ Бог, може входити до складу прислів 'їв, які наголошують на життєвій необхідності працювати: Святі хлібом не нагодують [3, с. 14].

Духовне звання у православній церкві nin має розмовний характер (з позначкою розм. зафіксовано в словнику [2, с. 789]). Служитель релігійного культу, який має це звання й здійснює богослужіння. Колективний досвід спілкування зі служителями релігійного культу (які по суті й за визначенням мають бути проповідниками християнської ідеї, еталоном поведінки в радості і в горі, глибоко розумітися на канонах православ'я) фіксує в народній пам'яті образ священика, який на щаблі духовного розвитку не стоїть вище від своєї пастви. Наприклад: Коли маєш cто кіn, то будеш nin [6, с. 24]; Як сто кіп, так $i$ nin [6, с. 24]; Ha me nin посвятився, щуоб по церкві крутився [6, с. 24]; Піп живе з олтаря, а писар 3 каламаря [6, с. 24]; Чиї ворота минеш, а попових не минеш [6, с. 24]; Попа одним обідом не нагодуєш [6, с. 24]; Нема дурнімого од попа: люди плачуть, а він співає [6, с. 24]; Гудимо попа, а піп як ягода [6, с. 24]; Попів гудьмо, а попами будьмо [6, с. 24]. Негативне ставлення до попів, зумовлене тяжінням більшості 3 них до матеріальних благ, а не до духовного зростання, викликає до життя низку паремій, що мають знижену 
оцінку: Повозив попа в решеті (про тих, хто потаївся на сповіді); Возить nопа в решеті (дурить кого); Будеш попа в решеті возити (дітей лякають, що отченашу не вміють; до речі, молитві українці надають виняткову вагу, відтак про небажання спілкуватися з Богом висловлюються в категоричній формі: Нема оченаш, нема хліба) [6, с. 22].

Паремії засвідчують прозоре ставлення чималого прошарку українців до церкви, ритуальних служб: Куди ходім, то ходім, - аби не до цееркви [6, с. 23]; На псалтир уже дзвонять, та нас не загонять [6, с. 23]; Нехай дзвонять, їх на панщуину не гонять [6, с. 23]; Дзвін до церкви скликає, а сам в ній не буває [6, с. 23]. Наголосимо, що ілюстративний матеріал взято зі збірки, укладеної М. Номисом (уперше побачила світ 1864 року), відтак таке ставлення до відправ, інституту церкви ніяк не можна пояснити впливом радянської ідеології, примусовим руйнуванням храмів, переслідуванням вірян. Українці протиставляють Бога і молитву, 3 одного боку, попам і церкві, з іншого.

Народ засуджує й показну віру в Бога, віру, яка не заснована на духовній потребі, а лише є наслідком данини традицій, звички до певних ритуалів: Набожний - як жид подорожній [6, с. 23]; Набожний! Якби такий кожний, то б увесь світ догори ногами перевернули [6, с. 23]; Святий та Божий! Свічки поїв, а поночі сидить [6, с. 23]; Постава свята, а сумління злодійське [6, с. 23]; Щодень Бога хвалить і щзодень Бога дурить [6, с. 23]; Рукою махаєш, а думкою скрізь літаєш (на молитві) [6, с. 23].

Ключові поняття в системі духовної народної культури зазвичай корелюються, вступаючи в бінарні опозиції: Бог - чорт, ангел - чорт, святий - біс і т. ін. Наприклад: Між людьми ангел, а дома чорт [6, с. 14]; Перед людьми святий, а дома - бісові рідня [3, с. 14]; До Бога важкий илях, а до пекла прямесенький [6, с. 23].

Антихрист, сатана, диявол уособлюють підлість, підступність, зрадництво, злобу тощо. Усе гірше, що оточує людину, несе їй страждання, нещастя, загибель, пов'язане з цими образами: Як не дасть Бог смерті, то чорти не візьмуть [3, с. 48]; На Бога дивиться, а чорта бачить [3, с. 57]; До Божого дару з чортовими ногами [6, с. 22]. Основні компоненти символічного значення слів сатана, диявол, антихрист і под. - «зло», «підлість», «зрада», «підступність», «нещастя», «загибель». У широкому абстрактному плані диявол (сатана) виразник ідеї конечності всього сущого [4, с. 76].

Український фольклор, зокрема паремійний корпус, можна вважати репрезентантом української душі, вдачі, світосприйняття. Ментальність визначає спрямованість людини, іiі цілі і мотиви життєдіяльності, певне світобачення, взаємини тощо, а народна творчість фіксує все це в пам’яті поколінь. Паремії акумулюють у собі тисячолітній життєвий досвід народу, його світобачення, поведінкові приписи, норми, відображають 
українську ментальність і духовність, маніфестують риси національного характеру, умонастрої народу. У часи хисткості віри звернення до християнських цінностей сприятиме корегуванню світогляду тих українців, хто як особистості сформувалися в період тотального войовничого атеїзму.

\section{Література}

1. Бабич Н. «Сила Божа» в народній фразеології / Надія Бабич // Богословський стиль української мови у контексті стилістичної науки : зб. науково-дидактичних праць. - Чернівці : Видавничий дім «Букрек», 2009. - С. 118 - 123.

2. Великий тлумачний словник сучасної української мови / Уклад. і голов. ред. В. Т. Бусел. - К. ; Ірпінь : «Перун», 2003. - 1440 с.

3. Вирган I. О. Російсько-український словник сталих виразів / Вирган І. О., Пилинська М. М. - Х. : Прапор, 2002. - 864 с.

4. Кононенко В. І. Символи української мови / Віталій Іванович Кононенко. - Івано-Франківськ: Плай, 1996. - 272 с.

5. Мокиенко В. М. Образы русской речи : Историко-этимологические и этнолингвистические очерки фразеологии / Валерий Михайлович Мокиенко. - Л. : Изд-во Ленингр. ун-та, 1986. - 280 с.

6. Українські приказки, прислів'я і таке інше. Уклав М. Номис / Упорядкув., прим та вступна ст. М. М. Пазяка. - К. : Либідь, 2004. - 352 с. - («Пам’ятки історичної думки України»).

7. Философский словарь / Под ред. И. Т. Фролова. - [4-е изд.]. - М. : Политиздат, 1980. - 444 с. 